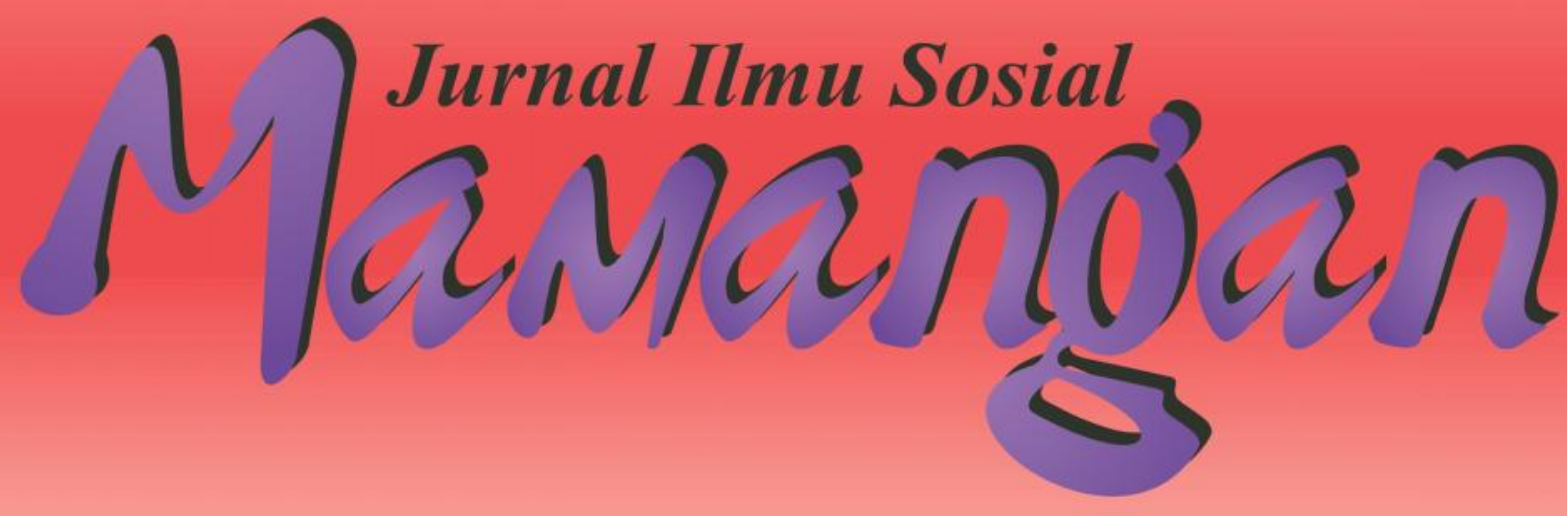

Peran Perantau Terhadap Pembangunan Di Jorong Galogandang, Nagari III Koto Kec. Rambatan, Kab. Tanah Datar Vivi Emita, Zusmelia \& Marleni

Julo-Julo Tani Buruh Perempuan Jorong Patamuan, Nagari Talu Kecamatan Talamu Kab. Pasaman Barat Sriwahyuni, Zusmelia \& Delmira Syafirini

Dari Petani Ke Penambang; Perubahan Sosial Ekonomi Di Jorong Koto Panjang, Nagari Limo Koto, Kabupaten Sijunjung

Melta Ardila Sari, Ardi Abbas \& Darmairal Rahmad

Strategi Masyarakat Multikultural Pasaman Barat Menghindari Konflik

Elly Kristin Debora, Dian Kurnia Anggreta \& Faishal Yasin

Konflik Sopir PO. Mitra Kencana Vs Pengemudi Betor di Air Bangis, Kab. Pasaman Barat

Helma Frida, Witrianto \& ZusneliZubir

Konflik Tanah Ulayat Antara Kamanakan Malakok VS Niniak Mamak Suku Tobo Di Nagari Padang Laweh, Kec. Koto VII, Kab. Sijunjung Welda Ningsih, Dian Kurnia Anggreta \& Rinel Fitlayeni 


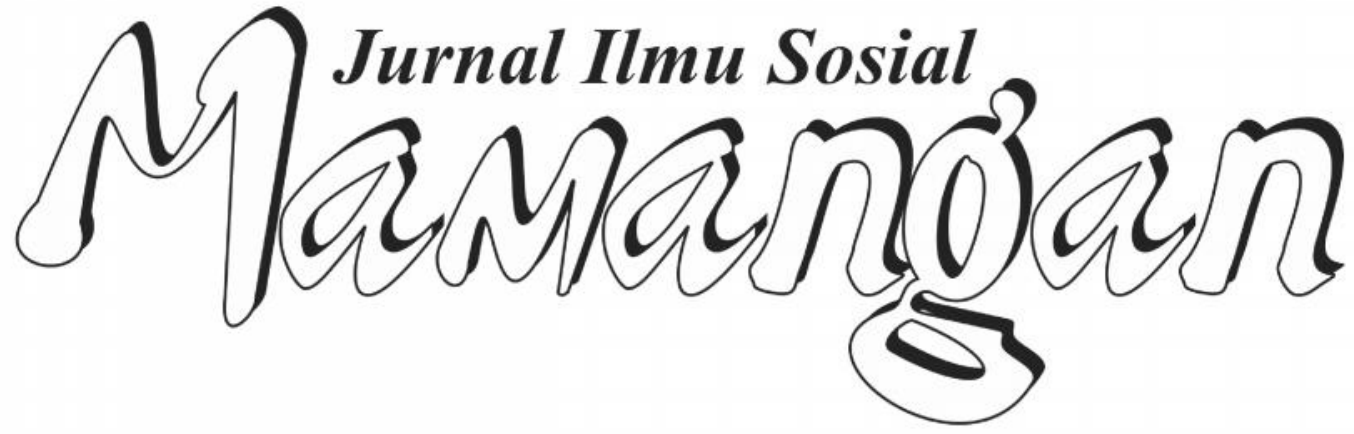




\section{Mitra Bestari}

Prof. Dr. Afrizal, MA. (FISIP, Unand Padang)

Dr. A. Latief Wiyata, M. Si. (Universitas Jember, Jember)

Prof. Dr. Badaruddin, M. Si. (FISIP, USU Medan)

Dr. Fikarwin Zuska, M. Si. (FISIP, USU Medan)

Nurus Shalihin, M. Si., Ph.D. (Fak. Ushuluddin IAIN Imam Bonjol Padang)

Dr. Semiarto A. Purwanto, M. Si. (FISIP, UI Jakarta)

Dr. Wahyu Wibowo, M. Si. (Universitas Nasional, Jakarta)

\section{Dewan Redaksi}

Dr. Zusmelia, M. Si.

Dr. Maihasni, M. Si.

Adiyalmon, S. Ag., M. Pd.

Firdaus, S. Sos., M. Si.

\section{Pemimpin Redaksi}

Firdaus, S. Sos., M. Si.

\section{Anggota Redaksi}

Dian Kurnia Anggreta, S. Sos., M. Si.

Rinel Fitlayeni, S. Sos., MA.

Surya Prahara, SH.

ISSN: 2301-8496

\section{Alamat Redaksi:}

Laboratorium Program Studi Pendidikan Sosiologi, STKIP PGRI Padang

Jl. Gunung Pangilun, Padang

Email: redaksimamangan@yahoo.com

Penerbit :

Program Studi Pendidikan Sosiologi, STKIP PGRI Padang

\section{Contac person :}

Firdaus (Hp. 085263881221/Email : daus gila@yahoo.com) 


\section{DAFTAR ISI}

Peran Perantau Terhadap Pembangunan Di Jorong Galogandang, Nagari III Koto Kec. Rambatan, Kab. Tanah Datar

Vivi Emita, Zusmelia \& Marleni

Julo-Julo Tani Buruh Perempuan Jorong Patamuan, Nagari Talu Kecamatan Talamu Kab. Pasaman Barat

Sriwahyuni, Zusmelia \& Delmira Syafirini

Dari Petani Ke Penambang; Perubahan Sosial Ekonomi Di Jorong Koto Panjang, Nagari Limo Koto, Kabupaten Sijunjung

Melta Ardila Sari, Ardi Abbas \& Darmairal Rahmad

Strategi Masyarakat Multikultural Pasaman Barat Menghindari Konflik

Elly Kristin Debora, Dian Kurnia Anggreta \& Faishal Yasin

Konflik Sopir P0. Mitra Kencana Vs Pengemudi Betor di Air Bangis, Kab. Pasaman Barat

Helma Frida, Witrianto \& Zusneli Zubir

Konflik Tanah Ulayat Antara Kamanakan Malakok VS Niniak Mamak Suku Tobo Di Nagari Padang Laweh, Kec. Koto VII, Kab. Sijunjung Welda Ningsih, Dian Kurnia Anggreta \& Rinel Fitlayeni. 


\title{
KONFLIK SOPIR PO. MITRA KENCANA VS PENGEMUDI BETOR DI AIR BANGIS, KAB. PASAMAN BARAT
}

\author{
Helma Frida1, Witrianto² \& Zusneli Zubir ${ }^{3}$ \\ ${ }^{1}$ Sekolah Tinggi Keguruan dan Ilmu Pendidikan (STKIP) PGRI Sumatera Barat \\ 2 Universitas Negeri Padang \\ ${ }^{3}$ Balai Pelestraian Nilai Sejarah dan Nilai Tradisional (BPSNT) Padang
}

\begin{abstract}
In 2003 the events that many casualties. Where this event originated from a dispute between the driver PO. Mitra Kencana with Pedicab driver Motor in getting the passengers on Air Bangis Nagari, in this event is not only a victim but a more serious matter is the lives that four people falling PO driver. Partners Ujung Gading Kencana of Nagari and the residents Nagari Air Bangis and many more injuries from the incident. The study included a qualitative study of History, therefore, the study of the social conflict between the driver PO. Mitra Kencana and Motor rickshaw driver in Pasaman from 2003-2006, carried out using the procedure History research, namely: (1) Heuristics, (2) source criticism, (3) interpretation, and (4) the presentation of research results in the form of writing scientific history or Historiography. The results of this study indicate that since the tragedy that occurred in 2003 in Pasaman, kususnya Air Bangis major events occurred which resulted in loss of life, be more careful if there is a problem among the community.
\end{abstract}

\section{Keyword : Social Conflict, Public Transport, Driver}

\begin{abstract}
ABSTRAK
Pada tahun 2003 terjadinya peristiwa yang banyak menelan korban. Dimana peristiwa ini berawal dari perselisihan antara sopir PO. Mitra Kencana dengan Pengemudi Becak Motor dalam memperebutkan penumpang di Nagari Air Bangis, dalam peristiwa ini tidak hanya korban materi namun yang lebih parah adalah korban jiwa yang berjatuhan yaitu empat orang sopir PO. Mitra Kencana dari Nagari Ujung Gading dan satu orang warga Nagari Air Bangis dan masih banyak lagi korban luka-luka dari peristiwa tersebut. Penelitian termasuk penelitian kualitatif Sejarah, oleh sebab itu kajian mengenai konflik sosial antara Sopir PO. Mitra Kencana dengan Pengemudi Becak Motor di Kabupaten Pasaman tahun 2003-2006, dilakukan dengan menggunakan prosedur penelitian Sejarah yaitu: (1) Heuristik, (2) kritik sumber, (3) interpretasi, dan (4) penyajian hasil penelitian dalam bentuk penulisan sejarah ilmiah atau Historiografi. Hasil penelitian ini menunjukkan bahwa semenjak tragedi yang terjadi pada tahun 2003 di Pasaman, kususnya Air Bangis tempat terjadinya peristiwa besar yang mengakibatkan korban jiwa, menjadi lebih berhati-hati apabila terjadi suatu masalah diantara masyarakat tersebut..
\end{abstract}

Kata Kunci : Konflik Sosial, Transportasi Umum, Pengemudi

Jurnal Ilmu Sosial Mamangan, Volume II Nomor 1, Januari-Juni 2013 | 38 


\section{PENDAHULUAN}

Konflik adalah fenomena kehidupan yang tidak dapat dipisahkan dari kehidupan masyarakat, baik konflik antar kelompok maupun antar individu. Benturan antar sesama akan selalu terjad karena adanya berbagai kepentingan dari sejumlah orang yang melakukan hubungan interaksi sosial, jadi konflik mungkin saja terjadi antara masyarakat akibat adanya perbedaanperbedaan kepentingan. Peristiwa yang terjadi di Nagari Air Bangis, Kabupaten Pasaman adalah salah satu contoh yang dapat disaksikan dari berbagai konflik yang terjadi di Indonesia, yaitu perseteruan antara Sopir PO. Mitra Kencana dengan Pengemudi Becak Motor pada bulan Januari 2003.

Perseteruan yang terjadi antara Sopir PO. Mitra Kencana yang merupakan warga dari Nagari Ujung Gading dan Pengemudi Becek Motor yang merupakan warga Nagari Air Bangis. Akibat dari peristiwa ini banyak menelan korban luka dan bahkan korban jiwa. Korban jiwa yang diakibatkan oleh peristiwa ini sebanyak lima orang yang terdiri dari satu orang warga Air Bangis dan empat orang Sopir PO. Mitra Kencana (Padang Expres, 2003).

Peristiwa ini bermula dari perselisihan antara pengemudi angkutan pedesaan PO. Mitra Kencana dengan Pengemudi Becak Motor yang berawal dari adanya persaingan dalam mendapatkan penumpang atau saling ambil penumpang. Karena memperebutkan lapangan pekerjaan yaitu penumpang di Nagari Air Bangis. Para sopir angkot beranggapan bahwa dengan adanya becak motor berarti kesempatan mereka untuk mendapatkan penumpang menjadi berkurang. Kecemburuan dalam memperebutkan penumpang dari kedua belah pihak yang dirasakan oleh kelompok Sopir PO. Mitra Kencana dan juga Pengemudi Becek Motor membuat keadaan kedua belah pihak menjadi semakin memburuk sehingga meluas dan melibatkan masyarakat kedua nagari.

Setelah kejadian saling memperebutkan penumpang antara Sopir PO. Mitra Kencana dengan Pengemudi Becek Motor di Nagari Air Bangis, masalah ini telah pernah dimediasi oleh Wali Nagari Air Bangis (Drs. Efif Syahrial), Wali Nagari Air Bangis mengumpulkan para pengemudi Becak
Motor dan juga Sopir PO. Mitra Kencana untuk membicarakan dan mencari jalan keluar atas masalah yang sedang terjadi, dalam pertemuan tersebut akhirnya dicapai suatu kesepakatan antara kedua belah pihak, dimana Wali Nagari Air Bangis telah membatasi jalur trek diantara kedua belah pihak yaitu, area Becak Motor hanya dibolehkan membawa penumpang khusus di daerah Air Bangis saja, sedangkan area untuk Angkot PO. Mitra Kencana adalah membawa penumpang dari batas Nagari Air Bangis ke Nagari lain.

Berdasarkan latar belakang di atas, maka peneliti tertarik untuk membahas masalah tersebut kedalam sebuah penelitian dengan judul "Studi Kasus: Konflik Antara Sopir PO. Mitra Kencana dengan Pengemudi Becak Motor di Nagari Air Bangis Kabupaten Pasaman 2003-2006".

\section{TINJAUAN PUSTAKA}

Ada beberapa studi yang pernah dilakukan tentang konflik sosial seperti yang dilakukan oleh Rani Alfrinalita, dalam Skripsinya yang berjudul "Konflik antara Nagari Saniang Baka dan Muaro Pingai di Kabupaten Solok 1975-2009. Yang menyatakan bahwa diantara dua Nagari memperebutkan tanah perbatasan antara Nagari Saniang Baka dan Muaro Pingai (Afrinalita, 2011).

Penelitian lainnya pernah dilakukan oleh Harto Kuncoro FIS-UNP, dalam Skripsinya yang berjudul "Konflik Sosial dalam Masyarakat Transmigran dengan Penduduk Asli Pulau Mainan di Sawahlunto Sijunjung 1965-1980", dimana kesimpulannya yaitu Konflik Sosial bersumber dari kecemburuan sosial yang berasal dari pemberian fasilitas kepada tranmigrasi. Sementara penduduk sekitar (asli) tidak mendapatkan fasilitas serupa, sehingga mengakibatkan pemicu terjadinya konflik (Kuncoro, 1995).

Penelitian relevan selanjutnya adalah penelitian Nurmalina Dewi Hartati Skripsi "Sengketa Tanah di Kanagarian Koto Tangah 1980-1999" menulis penyebab sengketa tanah di kanagarian di koto tangah, karena sudah meningkatnya mutu tanah tersebut, sehingga harga tanah meningkat dan masyarakat cenderung menjual tanahnya tanpa memperhatikan kaumnya mengenai 
yang akan dijual. Sehingga menimbulkan konfllik antar masyarakat (Hartati, 2002).

Refinaldi FIS-UNP dalam skripsinya yang berjudul "Konflik tanah Ulayat di Sumatera Barat" juga pernah melakukan penelitian tentang konflik sosial. Ia menyimpulkan bahwa sejak berlakunya UU. No. 05 Tahun 1960 tentang peraturan dasar pokok-pokok agraria, telah membuka peluang terjadinya penyimpangan kesewenangan pemerintah yang merugikan masyarakat adat, penyimpangan ini ditandai dengan semakin tampaknya kepemilikan tanah sebagai aset tanah ulayat dan kurangnya akses masyarakat terhadap tanah serta lemahnya potensi tawar rakyat dalam menyelesaikan maslah tanah (Refinaldi, 1995).

Penelian lainnya juga pernah dilakukan oleh Eri Surifman Jurusan Sejarah dan Peradaban Islam Fakultas ADAB IAIN Iman Bonjol Padang, dalam skripsinya yang berjudul "Konflik Pasaman Barat (Tinjauan Historis) tahun 2004", suatu tinjauan historis. Bahwa telah terjadi Konflik di Pasaman Barat pasca Revormasi seperti yang terjadi diantara Simpang Tiga Alin dengan Paraman Ampalu, dan juga Konflik Sosial yang terjadi diantara orang Sinuruik dan Tinggam (Surifman, 2004).

Lain halnya dengan peneliti ini, penelitian ini akan membahas tentang konflik yang terjadi antara warga Nagari Ujung Gading, Kecematan Lembah Melintang dan masyarakat Nagari Air Bangis Kecematan Lembah Melintang yang diawali dengan masalah memperebutkan penumpang antara Sopir PO. Mitra Kencana dengan Pengemudi Becak Motor, dalam hal ini peneliti ingin melihat sejarah dan juga dampak dari konflik yang telah terjadi di Kabupaten Pasaman Barat.

\section{METODE PENELITIAN}

Penelitian ini merupakan penelitian Sejarah dengan empat tahap, yaitu Pertama Heuristik, kedua Kritik Sumber dan Interen dan ketiga yaitu Interpretasi dan yang terakhir atau yang keempat yaitu Historiografi. Data yang digunakan adalah data Primer dan sekunder. Pengumpulan data dilakukan melalui observasi, wawancara dan studi dokumen. Informan Penelitian yaitu orang-orang yang terlibat langsung dalam konflik, yaitu sopir PO dan sopir becak motor. Traingulasi dilakukan melalui sumber dan masyarakat yang memahami peristiwa konflik

\section{PERISTIWA TERJADINYA KONFLIK}

Konflik yang terjadi di Nagari Air Bangis, Kecamatan Sungai Beremas, Kabupaten Pasaman Barat, Provinsi Sumatera Barat merupakan sejarah konflik terbesar yang terjadi di Sumatera Barat. Pihak yang berkonflik dalam peristiwa ini adalah pihak dari kelompok supir PO. Mitra kencana dengan pengemudi becak motor. Kedua kelompok tersebut sama-sama beroprasi di nagari air bangis.

Konflik ini tidak hanya terjadi antara kelompok supir PO. Mitra kencana dengan pengemudi becak motor saja, melainkan telah melibatkan kedua nagari yaitu Nagari Air Bangis dan Nagari Ujung Gading. Konflik antara supir PO. Mitra kencana dengan pengemudi becak motor banyak menelan korban luka-luka bahkan korban jiwa, selain korban luka dan jiwa yang diakibatkan oleh peristiwa ini juga terdapat kerugian materi yang besar karena banyaknya mobil dari masyarakat nagari air bangis yang hancur akibat pelampiasan masyarakat nagari ujung gading.

Peristiwa yang terjadi antara supir PO. Mitra kencana dengan pengemudi becak motor seperti yang dijelaskan di atas bahwa peristiwa ini mencuat ke permukaan setelah dibakarnya salah satu becak motor Milik Hajrizal masyarakat dari nagari air bangis oleh kelompok PO. Mitra Kencana di Nagari Ujung Gading. Selain melaporkan kasus tersebut ke kantor KAPOLSEK yang ada di Nagari Ujung Gading, Kecamatan Lembah Melintang oleh pemilik becak motor tersebut, masalah ini juga diambil alih dari pihak Nagari Ujung Gading, karena bagaimanapun yang terlibat dalam peristiwa tersebut adalah masyarakat dari nagari ujung gading yaitu sopir PO. Mitra Kencana merupakan masyarakat dari nagari ujung gading.

Tanggal 14 januari 2003 bertepatan malam hari Wali Nagari Ujung Gading ( $\mathrm{H}$. Za'im Ar) mangundang Wali Nagari Air Bangis (Efif Syahrial) untuk datang ke Parit Lamo (Perbatasan Kecamatan Koto Balingka dengan Ujung Gading) di rumah makan Eseh yang sekarang, untuk membicarakan perihal yang sedang terjadi, pada malam itu telah 
hadir Wali Nagari Ujung Gading beserta sekretaris (Padri), Muti yang merupakan pemilik bus antar kota PO. Pastra karena bus tersebut juga beroperasi di Nagari Air Bungis dan beberapa orang dari pihak pemilik PO. Mitra Kencana beserta sopirnya yang tidak disebutkan namanya dari keterangan Padri, namun undangan tersebut tidak bisa dihadiri oleh Wali Nagari Air Bangis. Sehubungan tidak adanya dari pihak Air Bangis yang datang dalam pertemuan yng telah direncanakan oleh Wali Nagari Ujung Gading membuat kelompok dari Sopir Po. Mitra Kencana menjadi Emosi.

Keterangan dari Efif Syahrial yang merupakan Wali Nagari Air Bangis pada waktu peristiwa terjadi saat diwawancarai dikediaman menjelaskan alasan ketidakhadiran Wali Nagari Air Bangis saat undangan Wali Nagari Ujung Gading karena keadaan yang memanas sehingga Efif Syahrial tidak bisa menghadiri pertemuan yang akan dilakukan oleh beberapa pihak dari Nagari Ujung Gading. Kesimpangsiuran kabar yang beredar oleh orang-orang yang tidak bertanggungjawab yang sengaja memperkeruh suasana, kabar yang menyerang ke air bangis sehingga keadaan yang sebelumnya tenang menjadi rusuh oleh pemberitaan tersebut.

Pada tanggal 15 Januari 2003 sekitar pukul 23.00 WIB, Kabupaten Pasaman Kembali bergejolak. Sedikitnya lima orang tewas dan satu orang kritis (Padang Expres, 2003), peristiwa ini terjadi sehari setelah undangan dari pihak Nagari Ujung Gading yang tidak bisa dihadiri, sehingga menjadikan emosi kelompok PO. Mitra kencana semakin menjadi.

Menurut penjelasan Iyan yang ditemui dirumahnya kejadian tersebut bermula dari seorang supir PO. Mitra Kencana, sebut saja namanya Joni (nama Samaran) meminum satu botol spertus, setelah itu Joni Mengamuk. Para Sopir PO. Mitra Kencana pada waktu itu sedang berkumpul di Kuamang (daerah Nagari Ujung Gading), Joni mengamuk seperti orang kesetanan mengancam akan membakar semua angkot PO. Mitra Kencana yang ada di tempat apa bila dari pihak PO. Mitra Kencana tidak segera pergi ke Nagari Air bangis untuk menyelesaikan masalah yang sedang terjadi. Pengakuan iyan pada malam itu beberapa orang diantara mereka dalam keadaan mabuk setelah minum-minuman yang memabukkan, kemudian berangkat ke Air Bangis dengan menggunakan angkot $\mathrm{PO}$. Mitra Kencana milik mereka sebanyak \pm 12 unit PO. Mitra Kencana yang berangkat, dengan jumlah orang sekitar 26 orang Sopir PO. Mitra Kencana bersama kernekkerneknya.

Afrizal menyatakan bahwa Joni yang disebutkan di atas adalah seorang sopir PO. Mitra Kencana bertempat tinggal di Ujung Gading namun memiliki sanak saudara di Air Bangis, dengan demikian masyarakat Air Bangis banyak mengenal Joni dan percaya akan perkataan yang diucapkannya. Malam tersebut Joni datang ke Air Bangis dengan tergesa-gesa menyatakan bahwa orangorang Ujung Gading dalam perjalanan ke Air Bangis untuk menyerang. Beberapa dari masyarakat air bangis sibuk akan memberitahu berita tersebut kepada masyarakat yang lainnya.

Sekelompok Sopir PO. Mitra Kencana yang berangkat menuju Air Bangis dengan tujuan untuk bertemu langsung dengan Wali Nagari Air Bangis tidak mengetahui bahwasanya Joni lebih dahulu sampai ke Air Bangis. Epi menuturkan bahwa ketika mereka sampai di pasar empat (Daerah Air Bangis) beberapa angkot PO. Mitra Kencana yang berada bagian depan diserang dan dilempari oleh bebatuan, melihat keadaan yang tidak diperkirakan akan seperti itu maka beberapa angkot PO. Mitra Kencana berbalik arah menuju pulang ke ujung gading, delapan unit PO. Mitra Kencana terus menuju arah depan walaupun mendapatkan serangan dari beberapa masyarakat air bangis dan empat unitnya lagi kembali ke ujung Gading.

Di sepanjang perjalanan menuju rumah Wali Nagari Air Bangis yang sebelumnya akan ditemui oleh para sopir PO. Mitra Kencana tersebut mendapatkan serangan berupa lemparan batu, dengan demikian sudah tidak mungkin akan bertemu dengan Wali Nagari, jangankan menemui Wali Nagari turun dari angkotpun tidak bisa karena banyaknya masa yang akan menuju kearah angkot PO. Mitra Kencana dari ujung Gading. Sesampainya disimpang tiga Pasar air bangis Angkot PO. Mitra Kencana berputar arah kemudian disaat berada di dapan kantor Wali Nagari Air Bangis 
langsung melempari kaca kantor tersebut hingga pecah.

Setelah kaca kantor Wali Nagari Air Bangis dilempari batu oleh sekelompok PO. Mitra Kencana kemudian angkot PO. Mitra Kencana yang dikendarai oleh sopir dari ujung gading melaju dengan kecepatan tinggi sehingga dalam perjalanan pulang tersebut, salah satu mobil nomor dua dari depan menabrak salah seorang warga air bangis yang bernama Yandra Alfedo yang berprofesi sebagai nelayan di Kampung Jambuo (pasar tiga) kemudian menabrak sebuah truk yang sedang parkir, setelah menabrak truk sehingga angkot PO. Mitra Kencana tersebut tidak bisa lolos karena sopir membawa angkot terjepit di Stir Angkot tersebut. Terjebaknya sopir angkot PO. Mitra Kencana yang dikendarai oleh Budi sehingga beberapa orang di dalamnya juga ikut tempat amukan masa, karena telah menabrak salah seorang warga Air Bangis, yang berada dalam angkot adalah Budi, Anto, dan Iyan. disinilah awal dari pertumpahan darah yang mengakibatkan banyak korban jiwa dan korban luka-luka berjatuhan.

Begitu juga dengan beberapa PO. Mitra Kencana lainnya yang tidak bisa meloloskan diri dari masa yang jumlahnya sangat banyak. Menurut Fahmi bahwa di tengah jalan raya terdapat beberapa kayu besar (kayu balok) yang sengaja diletakkan oleh orang Air Bangis untuk mnghalangi perjalanan PO. Mitra Kencana untuk kembali ke Ujung Gading, tidak hanya terdapat kayu, namun juga beberapa drum besar dengan sengaja dilektakkan, oleh sebab itu semua orang Ujung Gading yang datang ke Air Bangis menggunakan PO. Mitra Kencana di serang oleh masa dari Air Bangis.

Kejadian pada tanggal 15 Januari 2003 di Air Bangis membuat Trauma setip akan melintasi Nagari Air Bangis hingga sekarang, walaupun kejadian peristiwa tersebut 10 tahun yang lalu namun ingatan tentang peristiwa tentang peristiwa berdarah yang membuat beberapa teman seprofesinya meninggal dunia dengan tragis. Melihat langsung dengan mata kepalanya betapa tragis dan kejamnya perbuatan orang Air Bangis terhadap teman-temannya yang dibantai tubuh temannya tersebut dengan senjata tajam, ada yang dibelah dadanya dan ada juga yang dipukul dengan benda keras seperti kayu balok. Mereka tidak bisa berbuat banyak untuk menyelamatkan diri mereka masing-masing apalagi untuk melawan masa yang jumlahnya sangat banyak, kedatangan mereka ke Air Bangis hanya semata-mata untuk menemui Wali Nagari Air Bangis dan tidak untuk menyerang. Terlihat jelas bahwa kedatangan dari pihak PO. Mitra Kencana tidak untuk menyerang karena tidak ada ditemukan satupun senjata tajam yang dibawa oleh mereka. Hanya satu yang disesali bahwa beberapa diantara pihak PO. Mitra Kencana yang datang ke Air Bangis malam itu dalam keadaan mabuk dan dipengaruhi oleh alkohol, "ujar Sijum". Sehingga tidak bisa untuk melarikan diri.

Peristiwa malam tersebut banyak mengalami luka berat diantaranya Sijum, Anto, dan Bayan. Buyung Yiuyie menyebutkan bahwa ketiga orang tersebut dalam keadaan tidak sadarkan diri karena mendapatkan luka yang cukup serius di bagian kepala, seperti sijum mengalami luka bacok dikepalanya. Sampai sekarang belkas jahitan sebanyak 19 jaitan di bagian kepalanya masih ada akibat peristiwa tersebut. Banyaknya masyarakat Air Bangis yang menyerang sopir PO. Mitra Kencana pada tanggal 15 Januari 2003 malam itu namun ada juga yang berhati baik untuk menolong korban-korban yang dikroyok oleh masyarakat tersebut. Masyarakat Air Bangis yang melakukan aksi penganiayaan tersebut kebanyakan dari pemuda-pemuda Air Bangis yang tidak sadar akan perbuatannya menghilangkan nyawa seseorang, berbeda dengan masyarakat Air Bangis yang masih memiliki hati nurani mau menolong korban-korban yang berjatuhan, korban dari Ujung Gading dibawa dan disembunyikan dari massa yang ingin menghabisi seluruh yawa orang Ujung Gading yang ada di Air Bangis. Buyung Yiuyie melihat ketiga temannya tersebut dibawa oleh beberapa orang masyarakat setempat.

Pada tanggal 15 Januari 2003 malam terjadinya peristiwa tersebut merupakan malam yang penuh dengan pertumpahan darah karena baju yang dipakai oleh Safrizal basah dengan darah korban, ia menyelamatkan beberapa orang Ujung Gading dari massa dengan cara menyembunyikan korban diruangan Puskesmas Air Bangis yang penuh dengan rongsokan bangunan supaya tidak diketahui 
oleh masa yang ingin menghabisi nyawa mereka. Berbeda dengan Iyan yang beruntung bisa selamat dari peristiwa tersebut, pada waktu angkot PO. Mitra Kencana berhenti setelah menabrak truk yang ada di depan, ia masih memiliki waktu untuk keluar dari angkot tersebut sebelum dikerumuni oleh masa. Tanpa diketahui oleh mereka bahwa Iyan adalah Orang Ujung Gading, namun beberapa orang ada yang menanyai ia orang Ujung Gading atau tidak, Iapun tidak kehabisan akal untuk mengelabui masa dengan cara berbahasa logat Air bangis menjawab bahwa ia adalah orang Air Bangis. Setelah perhatian beberapa orang tidak tertuju padanya barulah Iyan melarikan diri ke arah Muara manuju hutan dan akhirnya ia pun selamat.

Aksi penganiyayaan yang dilakukan oleh beberapa pemuda Air Bangis pada malam itu tidak bisa diamankan oleh pihak kepolisisn Air Bangis karena jumlah masa yang cukup banyak menggunakan senjata tajam. Beberapa saat kemudian barulah berdatangan beberapa unit mobil ambulance yang diiringi oleh sejumlah polisi dari Ujung Gading untuk menjemput korban yang ada di Air Bangis. Korban yang ada langsung dibawa ke Ujung Gading, baik yang luka-luka ataupun yang sudah tak bernyawa. Korban tidak boleh dilihat langsung oleh pihak keluarga karena luka dari senjata tajam di tubuh korban tidak layak dilihat oleh keluarga dikhawatirkan pihak korban tidak kuat untuk melihat luka-luka di bagian tubuh si korban tersebut.

Korban yang diakibatkan oleh peristiwa ini lima orang tewas dan beberapa orang sopir PO. Mitra Kencana luka-luka. Tiga orang sopir PO. Mitra Kencana meninggal dunia ditempat yaitu (1) Budi (20 tahun) Profesi Sopir Po. Mitra Kencana alamat kampuang Brestagi Ujung Gading, (2) Samsul Bahri (24 tahun) Profesi Sopir PO. Mitra Kencana alamat koto Pinang, (3) Juli Fitri (33 Tahun) Profesi Sopir PO. Mitra Kencana alamat Ujung Gading dan satu orang diilarikan ke rumah sakit M.Jamil Yang bernama (4)Amat Isyar (27 tahun) Profesi Sopir PO. Mitra Kencana alamat pasar lamo, namun dalam perjalanan ke padang menuju RM M.Jamil iapun meninggal dunia. Sedangkan korban meninggal dunia dari masyarakat Air Bangis adalah satu orang yang bernama (5) Yandra Alfero (21 tahun)
Profesi nelayan yang merupakan korban dari tabrakan mobil PO. Mitra Kencana yang melaju kencang dari ujung gading, dan salah seorang sopir PO. Mitra Kencana dalam keadaan kritis sedang dilarikan ke rumah sakit M. Jamil, dan nyawanyapun dapat tertolong sedangkan korban luka berat yaitu Sijum, Anto dan Bayan, dan masih banyak korban luka lainnya (Padang Expres, 2003).

\section{UPAYA PENYELESAIAN KONFLIK}

Adapun upaya yang dilakukan untuk penyelesaian konflik antara sopir Po. Mitra Kencana dengan Pengemudi Becak Motor yang melibatkan masyarakat kedua Nagari sudah dilakukan beberapa kali yang ditangani oleh Niniak Mamak (pimpinan adat) Kedua Nagari, diadakan pertemuan antara kedua ninek Mamak dan beberapa tokoh masyarakat lainnya namun karena keadaan yang memanas perdamaian belum berpihak pada mereka, dimana Masyarakat Ujung Gading tidak mau berdamai begitu saja karena korban jiwa yang banyak dialami oleh Masyarakat Ujung Gading dan mereka minta Pertanggungjawaban dari Nagari Air Bangis, sehingga Niniak Mamak kedua Nagari angkat tangan dan tidak mampu mendamaikan cucu kamanakannya karena jalan satu-satunya hanyalah jalur hukum karena kasus ini sudah termasuk kasus pidana.

Senin 20 Januari 2003 upaya penyelesaian perseteruan antara Masyarakat Ujung Gading dengan Air Bangis yang berawal dari perselisihan antara sopir Po. Mitra Kencana dengan pengemudi Becak Motor mulai menunjukkan titik terang, sebelumnya bukan tidak ada upaya yang dilakukan oleh Wali Nagari kedua belah pihak, tetapi emosi masa diantara keduanya tidak bisa diatasi oleh Wali Nagari keduanya. Upaya yang dilakukan dalam penyelesaian ini adalah dipertemukannya kedua belah pihak yaitu Wali Nagari kedua belah pihak, Niniak Mamak kedua belah pihak, Tokoh Masyarakat, Alim Ulama dari kedua belah pihak. Pertemuan tersebut dipimpin langsung oleh Kapolda Sumatera Barat yaitu Brigjen Pol. Drs. Adang Firman beserta wakil Bupati Pasaman yang bernama Benny Utama, SH, berlangsung dalam suasana kekeluargaan diantara kedua belah pihak dimana kedua nagari yang bertetangga tersebut, selain itu masyarakatnya masih 
memiliki kekerabatan antara kedua Nagari. Acara pertemuan atau musyawarah tersebut berlangsung di hotel Hamco Sukamenanti Padang. Dalam pertemuan yang dipimpin oleh Adang Firman ini disimpulkan bahwasanya hal serupa tidak akan terjadi lagi dan kedua belah pihak sepakat untuk berdamai karena perdamaianlah satusatunya jalan yang paling terbaik untuk kedua belah pihak (Padang Expres, 2003)

Sedangkan bagi korban meninggal dunia akan mendapatkan asuransi jiwa, begitu juga dengan warga Air Bangis yang mengalami kerugian materi seperti beberapa unit mobil milik warga Air Bangis juga mendapatkan asuransi, dalam kasus ini semua mobil yang dibakar oleh warga Ujung Gading dinyatakan kasus kecelakaan agar mendapatkan asuransi. Walaupun mendapatkan asuransi jiwa berupa uang, tidak membuat pihak keluarga korban meninggal semudah itu akan lupa atas kejadian yang menimpa salah satu dari keluarganya.

Menurut Sumanto, Kramil yang bertugas di Air Bangis, hasil dari musyawarah yang telah disepakati tersebut disambut dengan gembira oleh seluruh masyarakat kedua nagari, dengan gembiranya masyarakat berencana untuk membuat syukuran dengan menyembelih seekor kerbau dan berdo'a bersama, tetapi hal tersebut tidak diperbolehkan oleh Kapolres kedua Nagari karena ditakutkan akan terjadinya hal-hal yang tidak diinginkan, biar bagaimanapun keluarga korban yang meninggal dunia sangat sulit untuk menerima kenyataan yang sebenarnya, dimana dalam peristiwa ini telah menghilangkan nyawa salah seorang anggota keluarganya.

Beberapa hari setelah pertemuan antara kedua belah pihak, kondisi diantara keduanya berangsur membaik, bahkan beberapa orang dari Ujung Gading sudah mulai melakukan aktivitas seperti biasanya yaitu berdagang ke Air Bangis, bagitu juga dengan masyarakat Air Bangis, sudah berani untuk melewati Ujung Gading. Namun berbeda dengan angkot PO. Mitra Kencana, setelah kejadian peristiwa tersebut tidak ada lagi beroperasi PO. Mitra Kencana sampai sekarang, karena beberapa angkot di tahan oleh kepolisian lantas dan diletakkan di kantor Polres Pasaman yaitu disimpang Empat dan Becak motor juga sudah tidak ada ditemukan di Air Bangis.

\section{DAMPAK KONFLIK TERHADAP SOPIR PO. MITRA KENCANA}

Setelah peristiwa yang terjadi di Nagari Air Bangis, menjadikan kehidupan Sopir PO. Mitra Kencana yang terlibat dalam peristiwa tersebut menjadikan mereka sebagai buronan pihak yang berwajib seperti Kepolisian, Sopir PO. Mitra Kencana menjadi tersangka dalam kasus ini terutama bagi Sopir PO. Mitra Kencana yang selamat dalam peristiwa tersebut. Beberap Sopir PO. Mitra Kencana tertangkap Seperti Pendi, Buyuong Yiuyie, Sijum, terutama Joni yang menurut pengakuan dari beberapa Sopir PO. Mitra Kencana sebagai profokator dari peristiwa tersebut. Pendi dan Buyung Yiuyie ditahan selama tujuh hari dalam tahanan kantor Polres Lubuk Sikaping. Sementara Joni babak belur dipukuli oleh keluarga korban meninggal (Budi) yang mengetahui bahwa Joni yang memberitahukan kedatangan Sopir PO. Mitra Kencana untuk menyerang ke Air Bangis. Joni yang sebagai dalang dari peristiwa tersebut setelah dibebaskan dari tahanan langsung pergi meninggalkan kampung halamannya dan pergi merantau, manurut keterangan beberapa sopir, Joni sampai sekarang tidak berani untuk pulang, kecuali pulang untuk melihat keluarganya, sekarang Joni berada di Batam. Dampak dari konflik yang terjadi di tahun 2003 terhadap kehidupan Sopir PO. Mitra Kencana menjadikan beberapa sopir beralih Profesi seperti di bawah ini.

Pendi sebelumnya seorang Sopir PO. Mitra Kencana dari Air Bangis ke Ujung Gading setelah peristiwa tersebut Pendi menikah dengan seorang perempuan dari Air Balam dan beralih profesi dari seorang sopir menjadi pedagang Perlengkapan rumahtangga khususnya elektronik seperti Magicom, Dispencer, televisi, dan lain sebagainya dan sekarang ia tinggal di Air Balam dan tinggal bersama keluarganya yang terdiri dari istri dan 3 orang anaknya. Kemudian Buyung Yiuyie sebelumnya seorang Sopir PO. Mitra Kencana sekarang beralih menjadi Karyawan PT. BMC milik Aburizal Bakre yang berada di Air Balam dan hidup dengan istri dan 5 anaknya di barak milik PT. BMC tersebut.

Namun beberapa orang masih berprofesi sebagai sopir tetapi beroperasi di Air Bangis. Sedangkat angkot PO. Mitra 
Kencana sudah tidak ada ditemukan semenjak peristiwa tersebut, dari sekian banyak angkot yang diberi nama PO. Mitra Kencana nemun beberapa angkot mengganti nama dari PO. Mitra Kencana menjadi Santen Balado, Haholongan dan sebagainya.

Beberapa sopir PO. Mitra Kencana terpaksa melarikan diri meninggalkan kampung halaman seperti Iyan yang meninggalkan kampung selama kurang lebih dua tahun, karena Iyan takut menjadi buronan polisi dan akhirnya Iyan terpaksa meninggalkan kampung halamannya. Sekarang keadaan sudah stabil dan kehidupan beberapa dari sopir yang ikut dalam peristiwa tersebut hidup bersamasama denga keluarganya, tiga tahun setelah kejadian tersebut Iyan akhirnya menikah dan sekarang sudah memiliki dua orang anak. Akan tetapi Profesi tetap sebagai sopir, dimana dahulu iyan sebagai kenek dari PO. Mitra Kencana kemudian beralih menjadi sopir PO. Mitra Kencana dan sekarang menjadi sapir travel dari ujung Gading dan sekitar Padang.

Sedangkan empat orang sopir PO. Mitra Kencana yang meninggal dunia dalam peristiwa ini terdiri dari tiga orang sopir yang belum berkeluarga dan satu orang sudah berkeluarga Yaitu Juli Fitri. Juli Fitri meninggalkan seorang istri dan satu orang putranya yang pada waktu itu baru berumur dua tahun, setahun setelah juli fitri meninggal dunia, istrinya meninggal dunia dan putranya di asuh oleh keluarga dari juli fitri sekarang putra Juli Fitri berumur dua belas tahun. Sedangkan Sijum salah seorang sopir yang kritis pada waktu itu masih berprofesi sebagai supir tetapi membawa penumpang dari Desa Baru ke Padang.

Peristiwa tragis ini telah merenggut nyawa tiga orang pemuda, yang masih muda dan masih belum berkeluarga yaitu Budi, Samsul Bahri, dan Amat Ishar. Budiman Putra atau dipanggil dengan budi digambarkan sebagai sosok pemuda dengan penampilan cakap, budi adalah alumni sekolah perawat kesehatan dikenal dengan sebagai pemuda berkelakuan baik dan disayangi dalam keluarganya. Keberadaannya dikampung berkaitan dengan selesainya pendidikan, dan keinginannya mendapatkan pekerjaan, karena itulah pihak keluarganya menfasilitasi dengan menyediakan sebuah mobil angkot yang kemudian dioperasikan sehari-hari untuk angkutan umum (Padang Expres, 2003).

\section{DAMPAK KONFLIK TERHADAP PENGEMUDI BECAK MOTOR}

Berbeda halnya dengan pengemudi Becak Motor yang ada di Air Bangis, dampak dari peristiwa di atas memuat pengemudi Becak Motor berhenti total menjadi pengemudi Becak Motor di Air Bangis, karena Profesi sebagai pengemudi Becak Motor bukanlah profesi yang sebenarnya melainkan pekerjaan sampingan dari profesi sebagai Nelayan yang sesungguhnya. Becak yang sebelumnya menyatu dengan motor di bongkar habis oleh semua pengemudi yang ada di Air Bangis karena takut akan menjadi buronan dari pihak Kepolisian, tidak ada satupun diantara pengemudi Becak Motor yang ditahan oleh Kepolisisan seperti Sopir Po. Mitra Kencana.

Hajrizal (34 tahun) Pemilik Becak Motor yang ditahan oleh beberapa orang sopir PO. Mitra Kencana di Air Balam kemudian dibakar di Ujung Gading. Lima tahun setelah kejadian tragis yang merenggut nyawa sebanyak lima orang Hajrizal meninggal dunia tepatnya pada tahun 2008 karena demam tinggi. Hajrizal meninggal dunia dan meninggalkan istri dan dua orang anaknya.

Becak motor yang berada di Air Bangis sudah tidak bisa ditemukan lagi, berbeda halnya dengan PO. Mitra Kencana yang sampai sekarang masih beroperasi walau tidak menggunakan nama PO. Mitra Kencana dan ada juga PO. Mitra Kencana yang masih bisa dilihat walaupun sudah tidak dipergunakan lagi karena rusak berat akibat dari peristiwa tersebut. Semenjak perisiwa tragis tersebut sampai sekarang tidak pernah ada becak motor yang beroperasi di Air Bangis, disamping itu karena penduduk Air Bangis sudah banyak yang memiliki sepeda motor sehingga mempermudah penduduk Air Bangis untuk bepergian ke tempat tujuan yang mereka tuju, apalagi ekonomi penduduk Air Bangis sekarang sudah meningkat dibandingkan sebelumnya.

\section{DAMPAK KONFLIK TERHADAP MASYARAKAT AIR BANGIS}

Dampak konflik ini terhadap masyarakat Air Bangis adalah seperti hari setelah malam berjatuhannya korban di Air 
Bangis tepatnya pada 16 Januari 2003 Bupati Pasaman (Baharuddin) turun langsung ke tempat kejadian beserta Polres Pasaman bersenjata lengkap untuk mengantisipasi kemungkinan terjadinya konflik kembali dan untuk mengamankan kedua belah pihak yang bertikai. Namun karena keadaan yang memanas, beberapa masyarakat Ujung Gading berkumpul di daerah perbatasan Nagari dengan memeriksa apakah ada orang Air Bangis yang lewat di daerahnya, Setiap mobil yang ingin pulang ke Air Bangis di tahan dan pemiliknya tidak boleh pulang ke Air Bangis. Saat bupati ingin pergi menyelesaikan permasalahan yang ada, bupati menjadi tempat pelampiasan dari emosi masyarakat Ujung Gading, mereka meminta agar permasalahan ini dapat terselesaikan dengan secepat mungkin. Melihat keadaan yang masih memanas akhirnya Bupati disuruh oleh Wali Nagari Ujung Gading untuk kembali pulang tanpa dapat mengumpulkan kedua belah pihak untuk berdamai.

Dua hari setelah peristiwa terjadi, tepatnya pada tanggal 17 Januari 2003, dua buah mobil truk milik orang Air Bangis dari Padang menuju Air Bangis, karena jalan satusatunya itu harus melewati Ujung Gading tapi situasi dan kondisi tidak memungkinkan untuk lewat maka dua mobil truk beserta sopirnya bersembunyi di simpang tiga Alin, tetapi tempat persembunyiannya diketahui oleh orang Ujung Gading. Beberapa orang Ujung Gading datang ke simpang Tiga Alin dan membawa mobil tersebut ke Ujung Gading sedangkan sopirnya dibiarkan untuk lolos, sesampainya di ujung gading satu diantara mobil tersebut yaitu mobil Colt Diesel BA 9047 JC dibawa ke tepi sungai yang ada di Ujung Gading tepatnya di bawah jembatan lalu dibakarnya, ada dua buah mobil yang dibakar oleh orang-orang Ujung Gading yaitu antara lain mobil Colt Diesel BA 9047 JC dan mobil jenis Colt Diesel BA 9019 DE (Padang Expres, 2003). Menurut Keterangan Rusdi Lubis, salah seorang masyarakat Ujung Gading, pada waktu pembakaran mobil Milik orang Air Bangis terjadi perdebatan yang sangat sengit yang ingin pergi ke air bangis untuk menyerang, karena mereka menyatakan bahwa nyawa harus di ganti dengan nyawa, disinilah terlihat kebijaksanaan Wali Nagari Ujung Gading ia tidak memperbolehkan warganya untuk pergi karena bukan jalan keluar yang baik untuk permasalahan yang mereka hadapi.

Masyarakat Air Bangis mempersiapkan segala sesuatunya apabila hal-hal yang tidak diinginkan terjadi, seperti kabar penyerangan dari orang-orang Ujung Gading. Beberapa orang Air Bangis berjaga-jaga di perbatasan Nagari. Beberapa warga Nagari Air Bangis merakit Bom sendiri yang biasa mereka gunakan untuk mencari ikan di Laut, tujuannya untuk berjaga-jaga karena mendengar kabar bahwa orang Ujung Gading akan mengepung Air Bangis mulai dari Sikabau, dengan mendengar kabar itu mereka menyusun strategi sendiri dengan membuat jadwal ronda setiap hari dan malamnya. Begitu juga aparat keamanan yang diturunkan oleh pemerintah pusat, sekitar 99 orang Brimob dikirim ke lapangan dan aparat keamana yang sebagian ada di Ujung Gading, Air Bangis dan juga Di simpang Tiga Air Balam untuk menghindari terjadinya peristiwa serupa.

Lalu ada juga seorang perempuan yang akan melahirkan dari Air Bangis yang bernama Aris yang dibawa dengan mobil ambulance ke RM M. Jamil, namun tidak diperbolehkan melewati Ujung Gading lalu memutar balik ambulance pulang ke Air Bangis. Karena keadaan Aris yang tidak bisa diatasi oleh bidan setempat maka Aris dibawa Ke RS M. Jamil denga menggunakan jalur Laut dengan kapal laut (Bot) yang bernama Kapal Tuan $\mathrm{Ku}$ Rao dengan Nahkoda Anih Pawang dan anaknya yang bernama Zukman dan Feri, Aris akan dibawa ke padang untuk melahirkan yang ditemani oleh seorang bidan yang bernama Rohana dan beberpa anggota keluarga Aris, dalam perjalanan menuju padang aris melahirkan seorang anak perempuan yang dibantu oleh Bidan Rohana dengan perlengkapan seadanya di atas kapal laut. Perjalanan ke padangpun dibatalkan, putri dari Aris diberi nama Riana Putri Ladika yang artinya anak perempuan dari Ibu yang bernama Aris yang dibantu persalinannya oleh Bidan Rohana, sedangkan Ladika nama pemberian Bupati Pasaman (Baharuddin), yang artinya lahir di atas kapal.

Banyaknya kerugian yang dialami oleh kedua belah pihak tidak membuat mereka menghentikan perbuatannya, malah mereka semakin menjadi, karena mereka tidak 
merasa bersalah dan menganggap lawan merekalah yang bersalah. Menurut keterangan Iyul salah satu warga Air Bangis, pada waktu itu ada sekitar tiga mobil yang dibakar oleh masa Ujung Gading, tidak hanya itu kemudian terjadi aksi pelemparan Bom Molotov, yang berawal ketika dua orang Polisi berboncengan dari Air balam menuju Air Bangis, sekitar pukul 01.00 dini hari ketika sampai dibungo Tanjuang (masih daerah Air Bangis) tiba-tiba datang percikan api kearah motor yang mereka kendarai dan tidak jelas siapa yang melempari dan dari mana datangnya percikan api tersebut, ternyata percikan api tersebut adalah Bom yang telah mereka siapkan dan mereka mengira kedua polisi tersebut adalah warga Ujung Gading, kedua polisi tersebutpun mengalami luka yang sangat serius sehingga harus dilarikan ke rumah Sakit M. Jamil Padang, dengan luka yang sangat serius sehingga kedua polisi terseut cacat kaki seumur hidup, dan diantara keduanya harus mengamputasi kakinya.

Korban aksi pelemparan Bom Molotov pada tanggal 18 Januari 2003 adalah Briptu Jhon Esamulya (26 tahun) dan Briptu Basrizal (25 tahun) yang di rawat di RSUP M. Jamil Padang. Keduanya mendapat kunjungan dari Sekdakrov Sumbar Drs. Rusdi Lubis Bersama Kepala Badan Kesatuan Bangsa dan Perlindungan Masyarakat Sumbar Sofyan SH, Kepala Pol. PP Sumbar Drs. Marzuki Onmar dan Kepala Biro Pembangunan Setdaprov Sumbar, Rombongan ini mengungkapkan perhatian mereka terhadap kondisi kedua polisi tersebut. Basrizal yang berkampung halaman di Tandikek Kabupaten Padang Pariaman baru menjalankan tugasnya selama dua bulan di Pasaman, namun Basrizal siap ditugaskan kembali setelah dia sembuh (Padang Expres, 2003).

Dengan keadaan yang semakin memanas Pemerintah Daerah menjemput Niniak Mamak Dari Air Bungis untuk mempertanggungjawabkan Perbuatan Cucu kamanakannya, sehingga niniak mamak Air Bangis yang bernama Afrizal (Datuk Rajo Mao) dibawa ke Polres simpang Empat, selain itu penjagaan yang ketat oleh aparat Keamanan semakin diperkuat, bahkan tidak memperboleh warga masyarakat baik masyarakat Ujung Gading maupun Air Bangis untuk berkumpul dengan sesama masyarakat, ditakutkan mereka akan menyusun siasat baru dalam peristiwa tersebut. Menurut keterangan Afrizal ia harus mempertanggung jawabkan atas Peristiwa yang telah terjadi, ia ditahan Di kantor polres Simpang Empat sebagai tersangka, kemudian ditindaklanjuti dan dibawa ke Polrea Lubuk Sikaping untuk mempertanggungjawabkan atas peristiwa yang terjadi di Air Bungis yang banyak mengakibatkan korban oleh Cucu kamanakannya.

Peristiwa tersebut membuat trauma masyarakat kedua nagari tersebut, terutama bagi keluarga korban yang meninggal dunia, korban materi, dan trauma juga dirasakan oleh pedagang-pedagang Ujung Gading dan bagi masyarakat Air Bungis yang melewati jalan Ujung Gading apabila ingin bepergian. Setelah beberapa tahun setelah kejadian tersebut, ditahun 2006 keadaan diantara kedua Nagari sudah dinyatakan aman dan begitu pula hubungan antar Masyarakat kedua nagari sudah menunjukkan perdamaian seperti semula kala. Setelah kejadian tersebut, setiap ada permasalahan yang terjadi antara kedua nagari tersebut langsung ditangani oleh Niniak Mamak, Wali Nagari dan pihak kepolisian setempat untuk menghindari terulangnya peristiwa besar tahun 2003 lalu, contohnya adalah masalah pencabulan seorang anak sekolah warga Ujung Gading yang terjadi di tugu Air Bangis pada bulan Juni 2012, masalah tersebut langsung ditangani oleh Niniak Mamak Wali Nagari kedua Nagari tersebut dengan tujuan tidak terjadi hal-hal yang tidak diinginkan.

\section{KESIMPULAN}

Konflik Yang Terjadi Antara Sopir PO. Mitra Kencana dengan Pengemudi Becak Motor yang beroperasi di Nagari Air Bangis adalah masalah dari perebutan penumpang, yang diawali dengan adu mulut sehingga Wali Nagari Air Bangis membatasi area untuk keduanya. Proses terjadinya konflik yaitu karena adanya Profokator, pada tanggal 15 Januari 2003 bertepatan pada malam hari terjadi peristiwa berdarah dimana empat orang Sopir PO. Mitra Kencana dari Ujung Gading Meninggal dunia, dan satu orang masyarakat Air Bangis, serta banyak korban luka-luka.

Penyelesaian Konflik Ini dilakukan dengan dilakukan pertemuan antara Nagari 
Air bangis dan Ujung Gading di hotel Hamco Sukamenanti yang terletak di Kota Padang. Yang di pimpin oleh Kapolda Sumatera Barat Adang Firman yang dihadiri oleh Wakil Bupati Pasaman Bapak Beny Utama dan juga perwakilan dari dua Nagari antara lain Muspika Wali Nagari, Niniak Mamak, Tokoh Masyarakat, serta Alim Ulama dari kedua Nagari tersebut.

\section{DAFTAR PUSTAKA}

Afrinalita, R. (2011). Konflik antara Nagari Saniang Baka dan Muaro Pingai di Kabupaten Solok 1975-2009. Padang.

Arifin, Zainal, D. (2007). Permusuhan dalam Persahabatan. Yogyakarta: Perpustakaan Nasional.

Hartati, N. D. (2002). Sengketa Tanah di Kanagarian Koto Tangah 1980-1999. Padang.

Kuncoro, H. (1995). Konflik Sosial Dalam Masyarakat Transmigran Dengan Penduduk Asli Maina di Sawah Lunto
Sijunjung 1965-1980. Padang.

Padang Expres, K. (2003a). Air Bangis di Guncang Bom, p. 1.

Padang Expres, K. (2003b). Pasaman Rukunlah Baliak, p. 13.

Padang Expres, K. (2003c). Ujung Gading-Air Bangis Berdamai.

Padang Expres, K. (2003d, January). Lima Tewas satu Kritis.

Rahardjo, D. M. (1998). Budaya Masyarakat Perbatasan. Jakarta: Bagian Proyek Pengkajian dan Pembinaan Masa Kini direktorat Sejarah dan Nilai Tradisional Direktorat Jenderal Kebudayaan Pendidikan dan Kebudayaan.

Refinaldi. (1995). Konflik Tanah Ulayat di Sumatera Barat. Padang.

Simanjuntak, B. A. (2009). Konflik Status dan Kekuasaan Orang Batak Toba. Jakarta: Yayasan Obor Indonesia.

Surifman, E. (2004). Konflik Pasaman Barat (Tinjauan Historis). Padang. 


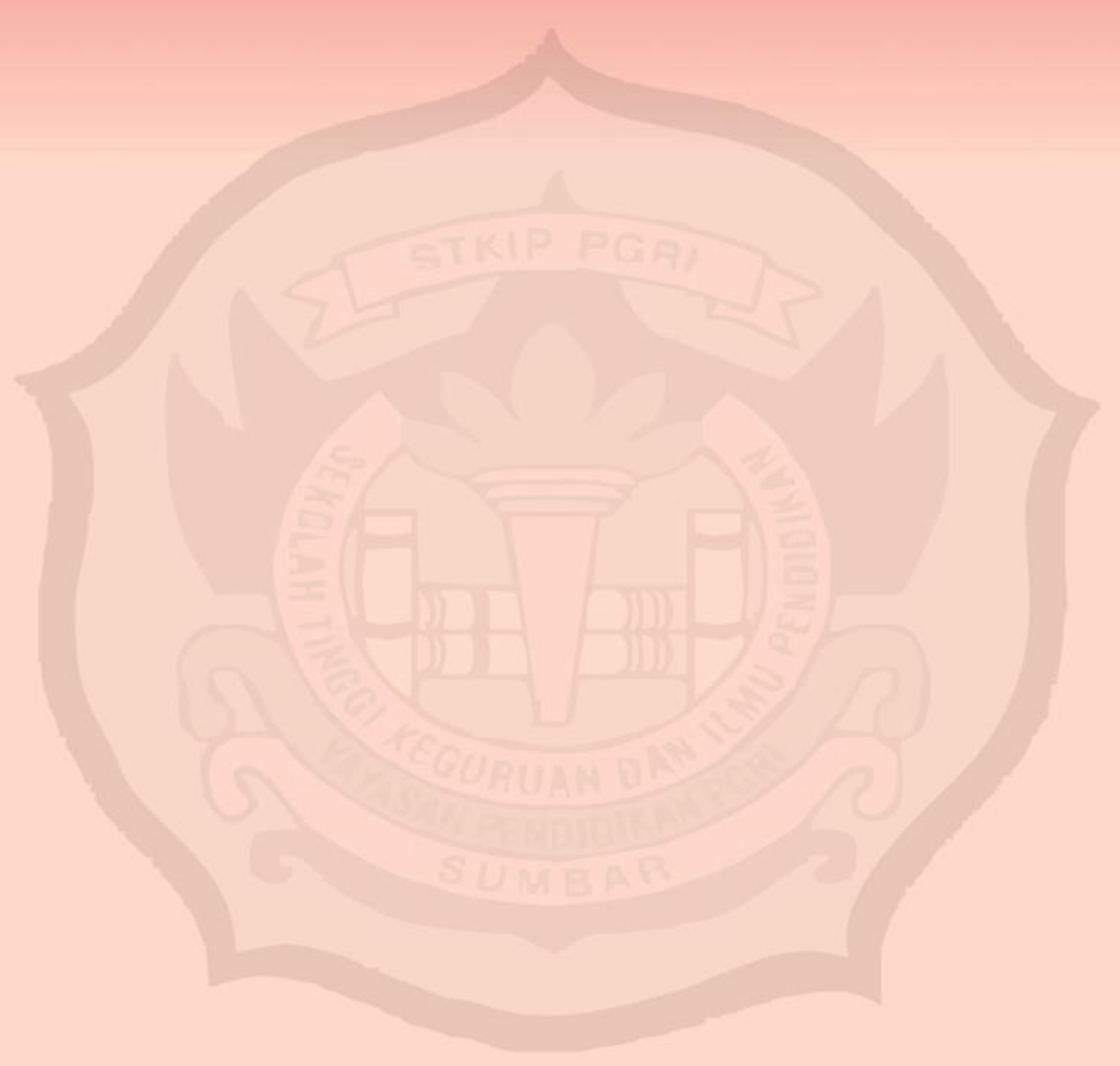

Penerbit :

Laboratorium Program Studi Pendidikan Sosiologi, STKIP PGRI Sumatera Barat

Kampus STKIP PGRI, Jl. Gunung Pangilun, Padang, Sumatera Barat

Email : redaksimamangan@gmail.com 